\title{
Pravo na privatnost i zaštitu osobnih podataka u knjižnicama: perspektive i dokumenti
}

\section{Right to Privacy and Protection of Personal Data in Libraries: Perspectives and Documents}

\section{Anita Konjicija-Kovač}

Biblioteka Muzičke akademije Univerziteta u Sarajevu, Sarajevo, Bosna i Hercegovina / Library of the Music Academy of the University of Sarajevo, Sarajevo, Bosnia and Herzegovina

anita.konjicija-kovac@mas.unsa.ba

\section{Informacije o članku / Article Info}

Primljen / Received 30. 9. 2020.

Prihvaćen / Accepted 2. 11. 2020.

Dostupan online / Available online: 15. 12. 2020.

\section{Ključne riječi / Keywords:}

privatnost, osobni podaci, zaštita privatnosti i osobnih podataka, knjižnice, međunarodni dokumenti

privacy, personal data, protection of privacy and personal data, libraries, international documents

\section{Sažetak / Abstract}

Privatnost kao pravni koncept nezaobilazan je dio modernog demokratskog društva i prepoznato je kao jedno od temeljnih ljudskih prava svakog građanina. Pravo na privatnost i zaštitu osobnih podataka zajamčeni su međunarodnim dokumentima o ljudskim pravima. U knjižničarskoj se djelatnosti pravo na privatnost i zaštitu osobnih podataka također garantira u dokumentima međunarodnih knjižničarskih udruženja u kojima se jasno naglašava da su knjižničari u svom radu obvezni da štite privatnost i osobne podatke svojih korisnika. Privatnost i osobne podatke je danas sve teže zaštititi, jer je pristup podacima jednostavniji i lakši zbog korištenja različitih i novih informacionih tehnologija, elektronskog komuniciranja, društvenih mreža, elektronskih baza podataka itd. Osobna se prava garantiraju međunarodnim dokumentima o zaštiti osobnih podataka, a štite se nacionalnim zakonima o zaštiti osobnih podataka. Glavni ciljevi rada su: problematizirati definiranje pojma privatnosti iz nekoliko perspektiva; problematizirati značaj prava na privatnost i zaštitu osobnih podataka u kontekstu knjižničarske profesije; dati pregled značajnijih međunarodnih dokumenata u području ljudskih prava u kojima se garantira i pravo na privatnost i zaštitu osobnih podataka; načiniti osvrt na značajnije međunarodne dokumente kojima se garantira pravo na zaštitu i tajnost osobnih podataka; i na kraju rad će dati pregled dokumenata međunarodnih knjižničarskih udruženja koji u svojim tekstovima ukazuju na značaj privatnosti i zaštite osobnih podataka u knjižničnoj djelatnosti.

Privacy as a legal concept is an unavoidable part of a modern democratic society and is recognized as one of the fundamental human rights of every citizen. The right to privacy and the protection of personal data are guaranteed by international human rights documents. In librarianship, the right to privacy and protection of personal data is also guaranteed in the documents of international library associations, which clearly emphasize that librarians are obliged in their work to protect the privacy and personal data of their users. Privacy and personal data are increasingly difficult to protect today, as access to data is simpler and easier due to the use of different and new information technologies, electronic communication, social networks, electronic databases, etc. Personal rights are guaranteed by international documents on protection of personal data and protected by national personal data protection laws. The main objectives of the paper are: to problematize the definition of the concept of privacy from several perspectives; problematize the importance of the right to privacy and protection of personal data in the context of the library profession; provide an overview of significant international documents in the field of human rights which also guarantee the right to privacy and protection of personal data; make a review of important international documents guaranteeing the right to protection and confidentiality of personal data; and finally, the paper will provide an overview of documents of international library associations that in their texts indicate the importance of privacy and protection of personal data in the library business. 


\section{Uvod - O pojmu privatnosti}

Da bismo problematizirali pojam privatnosti u što širem kontekstu, potrebno je da se nakratko vratimo još u antičko doba gdje koncept privatnosti svoje uporište ima u filozofskim raspravama grčkog mislioca Platona. On poručuje "neka potraže mjesto u državi gdje bi bilo najbolje udariti tabor, odakle bi najlakše držali na uzdi državljane ako se tko ne bi htio zakonima pokoravati" (Platon 2009, 163; prema Pavuna 2019, 5) i da nitko ne bi trebao imati "stana ni takve riznice u koje ne bi mogao ulaziti svatko tko će htjeti" (Platon 2009, 165; prema Pavuna 2019,5 ). U tom je smislu ideja države takva da "pretpostavlja potpunu transparentnost nasuprot privatnosti u svrhu ostvarivanja ideje pravednosti i dobra" (Pavuna 2019, 5). Kako navodi Pavuna, ključni momenat u razvoju privatnosti bio je "pretvaranje filozofskog koncepta, objektivnog prava u subjektivno pravo koje pripada svakom građaninu" (Pavuna 2019, 6). Tako se u 18. stoljeću privatnost pojavljuje kao "pravo privatnog vlasništva" (Pavuna 2019, 6, 7), što potvrđuje Povelja o pravima Sjedinjenih Američkih Država iz 1791. koja u 4. amandmanu građanima jamči "nepovredivost vlastite osobe, mjesta stanovanja, dokumenata i imovine od neosnovanih pretraga i zapljena" (Pavuna 2019, 7). Moderno poimanje privatnosti kao "prava" na privatnost započinje krajem 19. stoljeća kada su dva mlada bostonska odvjetnika, Samuel Warren i Louis Brandeis, u Harvard Law Reviewu 1890. objavili članak pod naslovom The right to privacy ("Pravo na privatnost", v. Warren i Brandeis 1890) u kojem sintagmom right to be let alone ("pravo biti ostavljen na miru") privatnost opisuju kao uobičajeno pravo koje je sadržavalo zaštitu "nepovrjedive osobnosti" svakog pojedinca. To bi značilo da svaki pojedinac ima pravo odabrati da li će s drugima podijeliti ili ne informacije o svom privatnom životu (navikama, postupcima) i na taj način zaštititi svoj psihološki integritet vršeći kontrolu nad informacijama koje utiču na individualnost, osobnost tog pojedinca. Članak mnogi nazivaju "rođenjem" prava na privatnost, koji je stoljeće poslije ugrađen u američko pravosuđe kao i u zakone mnogih europskih država. Brojni sudovi su usvojili obrazloženja Warrena i Brandeisa, iako postoje i oni koji kažu da su Warren i Brandeis zapravo samo prepisali ono što je već postojalo kao dio opće zakonske regulative (prema Glancy 1979).

Prema pisanju R. Clarka (2016) privatnost je interes koji pojedinci imaju u održavanju "osobnog prostora”, bez uplitanja drugih ljudi i organizacija. Bitna je

\section{Introduction - About the concept of privacy}

In order to problematize the concept of privacy in the broadest possible context, it is necessary to briefly go back to ancient times where the concept of privacy has its stronghold in the philosophical discussions of the Greek thinker Plato. He says "let them look for a place in the state where it would be best to pitch their camp, from where it would be easiest to keep the citizens in check if someone do not want to obey the laws" (Plato 2009, 163; quoted from Pavuna 2019,5 ) and that no one should have "residence nor such treasury that anyone who wants could not enter" (Plato 2009, 165; quoted from Pavuna 2019, 5). In this sense, the idea of the state is such that it "presupposes complete transparency versus privacy for the purpose of realizing the idea of justice and property" (Pavuna 2019, 5). According to Pavuna, the key moment in the development of privacy was "the transformation of the philosophical concept, objective law into subjective law that belongs to every citizen" (Pavuna 2019, 6). Thus in the $18^{\text {th }}$ century privacy appeared as "the right of private property" (Pavuna 2019, 6, 7), which is confirmed by the Bill of Rights of the United States of America from 1971, which in $4^{\text {th }}$ Amendment guarantees citizens "to be secure in their persons, houses, papers, and effects, against unreasonable searches and seizures" (Pavuna 2019, 7). The modern notion of privacy as a "right" to privacy began in the late $19^{\text {th }}$ century when two young Boston lawyers, Samuel Warren and Louis Brandeis, published an article in the Harvard Law Review in 1890 entitled The right to privacy (Warren i Brandeis 1890) in which by syntagm right to be let alone describe privacy as a customary right that included the protection of the "inviolable personality" of each individual. This would mean that each individual has the right to choose whether or not to share with others information about their private life (habits, actions) and thus protect their psychological integrity by controlling information that affects the individuality, personality of that individual. The article is called by many the "birth" of the right to privacy, and a century later was incorporated into the America's judiciary as well as into the laws of many European countries. Numerous courts have adopted the reasoning of Warren and Brandeis, although there are those who say that Warren and Brandeis actually only transcribed what already existed as part of the general legislation (quoted from Glancy 1979).

According to R. Clarke (2016), privacy is the interest that individuals have in maintaining 'personal 
iz nekoliko perspektiva: filozofske, psihološke, sociološke, ekonomske, političke. S tim u vezi isti autor (Clarke 2016) navodi kako filozofska perspektiva ustvari dotiče pitanja koncepta "ljudskog dostojanstva", integriteta, individualne autonomije i samoodređenja. U nekim tradicijama i jurisdikcijama, to su ideje koje podupiru pojam i značaj ljudskih prava. Psihološka perspektiva definira misao da je ljudima općenito potreban privatni prostor. To se odnosi i na "javnost", kao i na ono što se događa iza "zatvorenih vrata". Sociološki, ljudi moraju biti slobodni družiti se s drugima, biti podložni širokim društvenim običajima, ali bez stalne prijetnje da će ih se u tim akcijama promatrati. U ekonomskoj perspektivi, Clarke (2016) navodi da je zastrašujući učinak koji nadzor nad privatnošću sa sobom donosi, gušeći "inovacije". U tom smislu inovatori odstupaju od normi i smatraju se ugroženima ako im nedostaje privatnog prostora u kojem bi mogli eksperimentirati. I na kraju, politički, ljudi moraju biti slobodni razmišljati, raspravljati i djelovati. Isti autor (Clarke 2016) tvrdi da privatnost nipošto nije jednodimenzionalna, nego višestruka, sveobuhvatna, pa razlikuje: privatnost osobe, privatnost osobnog ponašanja, privatnost osobne komunikacije, privatnost osobnih podataka (često označenu i kao privatnost podataka - data privacy i informacijsku privatnost - information privacy), privatnost osobnog iskustva (v. više u Clarke 2016). Negdje na tom tragu i autorica Horvat (Horvat i Živković 2012, 29) definiraju privatnost kao intimu čovjeka, njegov osobni i obiteljski život, a pravo na privatnost pravo je čovjeka da bude sam kad želi i da podatke o sebi ne mora dijeliti s drugima. Autorica navodi i to da pravnici privatnost promatraju s različitih aspekata te tako razlikuju prostornu, informacijsku i komunikacijsku privatnost (v. više u Horvat i Živković 2012).

Kada govorimo o informacijskoj i komunikacijskoj privatnosti, neophodno je naglasiti da se informacijska privatnost odnosi upravo na "osobne podatke o pojedincu koji se prikupljaju, obrađuju i koriste u različite svrhe" (Horvat i Živković 2012, 30), a uređuje se zakonima o zaštiti osobnih podataka. U osobna se prava između ostalih ubraja i pravo na čast i ugled, odnosno "poštovanje dostojanstva čovjeka", koje je u digitalnoj sredini dobilo na važnosti jer ga je teže zaštititi nego ikad ranije (Horvat i Živković 2012, 31) s obzirom na sve veće prisustvo društvenih mreža u svakodnevnom životu, raznovrsnost informacionih tehnologija koje koristimo, dostupnost digitalnih medija i sl. Nadalje, među osobnim pravima tu su, po Horvat (Horvat i Živković 2012), još i pravo na vlastitu sliku (lik), pravo na identitet itd. space', without the interference of other people and organizations. It is important from several perspectives: philosophical, psychological, sociological, economic, and political. In this connection, the same author (Clarke 2016) states that the philosophical perspective actually touches on the issues of the concept of "human dignity", integrity, individual autonomy and self-determination. In some traditions and jurisdictions, these are ideas that support the notion and significance of human rights. The psychological perspective defines the idea that people generally need private space. This also applies to the "public", as well as to what is happening behind "closed doors". Sociologically, people must be free to associate with others, be subject to broad social customs, but without the constant threat of being observed in these actions. From an economic perspective, Clarke (2016) states that the intimidating effect that privacy control brings with it is stifling "innovation". In this sense, innovators deviate from the norms and are considered vulnerable if they lack a private space in which they could experiment. And finally, politically, people must be free to think, discuss and act. The same author (Clarke 2016) claims that privacy is by no means one-dimensional but multiple, comprehensive, so he distinct: privacy of a person, privacy of personal conduct, privacy of personal communication, privacy of personal data (often referred to as data privacy and information privacy), privacy of personal experience (see more in Clarke 2016). Somewhere on this trail, the author Horvat (Horvat and Živković 2012, 29) also defines privacy as a person's intimacy, his personal and family life, and the right to privacy is a person's right to be alone when they want, and not to have to share information about themselves with others. The author also states that lawyers view privacy from different aspects, and so distinguish between spatial, informational and communication privacy (see more in Horvat and Živković 2012).

When we talk about information and communication privacy, it is necessary to emphasize that information privacy refers to "personal data about an individual that is collected, processed and used for various purposes" (Horvat and Živković 2012, 30), and is governed by personal data protection laws. Among other things, personal rights include the right to honor and reputation, i.e. "respect of human dignity", which has become important in the digital environment because it is harder to protect it than ever before (Horvat and Živković 2012, 31) given the growing presence of social networks in everyday life, the variety of information technolo- 
Privatnost je s druge strane važan element " $i$ u autonomiji individualnosti" (McMenemy 2016, 1). Bez prava na privatnost, kako to definira McMenemy $(2016,1)$, nismo u mogućnosti biti potpuno svoji. Mnogo onoga što nas čini ljudima dolazi iz naših interakcija $\mathrm{s}$ drugima u našoj privatnoj sferi gdje pretpostavljamo da nas nitko ne promatra. Privatnost se tako odnosi na ono što kažemo, uradimo, a možda čak i na ono što osjećamo (McMenemy 2016, 1, 2). Privatnost je i "pravo biti slobodan od neopravdanog zadiranja (...)" (Law 2015), a neophodna je i za "slobodu, neovisnost i ljudsko dostojanstvo" (Schneier 2015, 273).

Još je prije 50-ak godina Alan Westin, jedan od najznačajnijih autora u području privatnosti, istakao njenu važnost u svojoj knjizi Privacy and Freedom iz 1967. te je napravio detaljan povijesni pregled razvoja pojma privatnosti u okviru političke misli na zapadu, naglašavajući da je privatnost zapravo mogućnost svakog pojedinca da za sebe odredi na koji će način, kada, kome i do koje mjere biti prezentirani podaci o njemu (Westin 1967, 7; prema Pavuna 2019,18$)$. U tom smislu, privatnost je i pravo svakog pojedinca da bude zaštićen od nedopuštenog uplitanja u njegov osobni život, posao, obitelj, objavljivanjem informacija o njemu ili neposrednim fizičkim mjerama (Michael 1994). Privatnost u kontekstu demokracije i građanskih prava, prema Cohen (2016), "štiti našu subjektivnost od sveprisutnih komercijalnih napora $\mathrm{i}$ vladinih aktera da pojedince i zajednice, učine transparentnima i predvidljivima. Privatnost je neizostavna značajka demokracije u kojoj pojedinac zadržava svoj identitet pridonoseći njegovoj građanskoj dužnosti." (prema: IFLA. The right to privacy in the digital age, 1).

\section{Pravo na privatnost i zaštitu osobnih podataka u knjižnici}

U knjižničarstvu je definiranje privatnosti ustvari "vitalno etičko područje za kojim moramo tragati" (McMenemy 2016, 3) u knjižničarskoj profesiji, što znači da knjižničari u svom radu imaju obvezu štititi privatnost svojih korisnika. To potvrđuju i IFLAin Etički kodeks za knjižničare i druge informacijske djelatnike, mnogi dokumenti i izjave koje su donijela međunarodna knjižničarska udruženja. No, nameće se pitanje koji su to podaci koje knjižničari trebaju štititi? To su prvenstveno osobni podaci, koji se u skladu sa zakonima o zaštiti osobnih podataka definiraju kao oni podaci, odnosno one informacije na temelju kojih se identificira određeni pojedinac, fizička osoba. To npr. prema Brezaku (1997) mogu biti činjenični osobni podaci (ime, adresa, dob, spol gies we use, the availability of digital media, etc. Furthermore, among personal rights there are, according to Horvat (Horvat and Živković 2012), the right to one's own image (character), the right on identity, etc.

Privacy, on the other hand, is also "an important element in the autonomy of the individual" (McMenemy 2016, 1). Without the right to privacy, as defined by McMenemy $(2016,1)$ we are unable to be completely our own. Much of what makes us human comes from our interactions with others in our private sphere where we assume no one is watching us. Privacy thus refers to what we say, do, and perhaps even how we feel (McMenemy 2016, 1, 2). Privacy is also "the right to be free from unjustified interference (...)" (Law 2015), and it is also necessary for "freedom, independence and human dignity" (Schneier 2015, 273).

As far back as 50 years ago, Alan Westin, one of the most important authors in the field of privacy, emphasized its importance in his book Privacy and Freedom from 1967 and made a detailed historical overview of the development of the concept of privacy within political thought in the West, emphasizing that privacy is actually the ability of each individual to determine for themselves how, when, to whom and to what extent information about them will be presented (Westin 1967, 7; quoted from Pavuna 2019, 18). In that sense, privacy is also the right of every individual to be protected from unauthorized interference in the personal life, work, family, by publishing information about them or by immediate physical measures (Michael 1994). Privacy in the context of democracy and civil rights, according to Cohen (2016) "protects our subjectivity from the pervasive efforts of commercial and government actors to render individual and communities fixed, transparent and predictable. Privacy is an indispensable feature of a democracy where an individual maintains his identity while contributing to their civic duty" (quoted from: IFLA. The right to privacy in the digital age, 1).

\section{The right to privacy and protection of personal data in the library}

In librarianship, defining privacy is actually "a vital ethical area that we must seek" (McMenemy 2016, 3 ) in the library profession, which means that librarians in their work have an obligation to protect the privacy of their users. This is confirmed by IFLA's Code of Ethics for Librarians and other Information Workers, many documents and statements that were issued by international library associations. But 
i sl.), podaci o nekoj osobi koji sadrže vrijednosne sudove (napredovanje, preporuke, mišljenje) i podaci o namjerama korisnika podataka (prema: Horvat i Živković 2012, 47).

Svrha zaštite osobnih podataka je zaštita privatnog života pojedinca u okviru temeljnih ljudskih prava i sloboda vezanih za prikupljanje, obradu i prijenos osobnih podataka na temelju dokumenata Ujedinjenih nacija, Europske unije, Vijeća Europe itd. Kako navodi Horvat (2002) zaštita osobnih podataka utemeljuje se na nekoliko osnovnih načela, a to su među prvima da se osobni podaci moraju prikupljati na zakonit način i za opravdanu svrhu; da moraju biti relevantni, ne preopširni, točni i redovito osuvremenjivani. "Svaki pojedinac mora imati pravo uvida u svoje podatke i ima pravo zatražiti njihov ispravak, ako smatra da nisu točni. Podaci moraju biti zaštićeni tako da se spriječi uvid neovlaštenih osoba ili potpun gubitak podataka" (Horvat 2002). U tom smislu, osobni su podaci zaštićeni zakonima u kojima se ujedno mora zajamčiti i sigurnost $\mathrm{i}$ tajnost osobnih podataka. Naravno, zadaća knjižničara je da u svojoj praksi zagovaraju, ali i provode mjere zaštite osobnih podataka.

$\mathrm{S}$ ciljem da podigne svijest javnosti o zaštiti privatnosti i osobnih podataka, prikazujući dobre prakse iz te oblasti, Vijeće Europe je 28. siječanj proglasilo Europskim danom zaštite osobnih podataka, koji prvi put počinje da se obilježava 2006, što nam dodatno potvrđuje činjenicu da je zaštita privatnosti jedna od temeljnih vrijednosti knjižničarske struke, a danas se uz najnovija tehnološka i društvena dostignuća rad knjižničara oblikuje u segmentu ne samo zaštite nego i zagovaranja privatnosti u "digitalnom dobu".

S obzirom na to da zakoni o zaštiti osobnih podataka definiraju to da se ti podaci sakupljaju u određene svrhe za koje je nositelj tih informacija dao dozvolu, osobni se podaci ne bi smjeli koristiti mimo tih odredbi, mada su zlouporabe u području osobnih podataka itekako prisutne. S tim u vezi, koje će (osobne) podatke knjižnica tražiti od korisnika pri upisu, knjižnica odlučuje sama, ali za sve podatke koje knjižnica sakuplja, mora postojati razlog zašto su traženi, odnosno u koje svrhe će se koristiti (obično su to podaci o imenu i prezimenu, datumu rođenja, zanimanju, adresi, broju telefona, e-mailu i sl.). Podaci o posudbi građe (npr. o najtraženijim naslovima) sakupljaju se uglavnom u statističke svrhe, radi planiranja nabavne politike. Pretraživanja koja korisnici obavljaju na računarima u knjižnicama također ostaju zabilježeni pa ih je s vremena the question arises: What is the data that librarians need to protect? These are primarily personal data, which in accordance with the laws on personal data protection are defined as those data, i.e. those information on the basis of which a certain individual, natural person is identified. For example, according to Brezak (1997), this can be factual personal data (name, address, age, gender, etc.), data on a person that contain value judgments (promotion, recommendations, opinion) and data on the intentions of data users (quoted from Horvat i Živković 2012, 47).

The purpose of personal data protection is to protect the private life of an individual within the framework of fundamental human rights and freedom related to the collection, processing and transfer of personal data based on documents of the United Nations, the European Union, the Council of Europe, etc. According to Horvat (2002), the protection of personal data is based on several basic principles. The first is that personal data must be collected in a lawful manner and for a justified purpose; they must be relevant, not too extensive, accurate and regularly updated. "Every individual must have the right to access their data and have the right to request their correction if they believe that they are inaccurate. Data must be protected in such a way as to prevent unauthorized access or complete loss of data" (Horvat 2002). In that sense, personal data are protected by laws in which the security and confidentiality of personal data must be also guaranteed. Of course, the task of librarians is to advocate in their practice but also to implement measures to protect personal data.

In order to raise public awareness about the protection of privacy and personal data, showing good practices in this area, The Council of Europe declared 28 January as a European Data Protection Day, which begins to be celebrated for the first time in 2006, that further confirm to us the fact that the protection of privacy is one of the fundamental values of the library profession, and today, with the latest technological and social achievements, the work of librarians is shaped in the segment of not only protection but also in advocacy of privacy in the "digital age".

As personal data protection laws define that this data is collected for certain purposes which the holder of this information has given permission for, personal data should not be used outside these regulations, although abuses in the field of personal data are very present. With this in connection, which (personal) data the library will ask from the user when enrolling, the library decides for itself, but for all 
na vrijeme potrebno brisati (Horvat 2002). Uz podatke o korisnicima, u knjižnici se čuvaju i podaci o knjižničnom osoblju, podaci o dobavljačima, donatorima itd. (Horvat 2002).

U nekim je državama prikupljanje osobnih podataka uređeno zakonskim propisima koji se tiču i knjižnica, kao npr. u Norveškoj, gdje postoji posebno tijelo državne uprave koje mora dati dopuštenje narodnim knjižnicama da uz utvrđene uvjete smiju prikupljati podatke o korisnicima. U Velikoj Britaniji je Zakon o zaštiti podataka na snazi od 1984., i odnosi se i na knjižnice. Prema njemu je svaki voditelj neke ustanove koja prikuplja određene podatke u strojno čitljivom obliku dužan prijaviti da se ti podaci prikupljaju. U Sjedinjenim Američkim Državama postoje "propisi o tajnosti podataka o posudbi", i ne samo to nego se čak "jamči i tajnost korisničkih pitanja" (Horvat 2002).

Iz navedenog možemo zaključiti da je tajnost podataka o korisnicima i podataka o korištenju građe i informacija važna iz praktičnih i moralnih razloga, s obzirom na to da je u današnje vrijeme zbog jednostavnijeg pristupa podacima uvođenjem novih informacijskih tehnologija i postojanja različitih elektronskih baza podataka, privatnost ugroženija nego ikad prije (Gorman 2000, 151). "Pojedinac se stoga može s pravom bojati da bi mu neovlašteni uvid u njegove osobne podatke mogao onemogućiti dobivanje neke usluge, povlastice itd. Također se može pretpostavljati da podaci ne moraju uvijek biti točni ili ne moraju biti točno protumačeni odnosno da se mogu tumačiti na štetu pojedinca" (Horvat 2002). S druge strane i "države se posebno boje da mogućnosti da velik broj osobnih podataka o njihovim građanima bude prenesen izvan njihovih granica" (Horvat 2002).

Jasno je da bez povjerljivosti osobnih podataka o pojedincu nije moguća ni zaštita čovjekove privatnosti (Injac 2008, 36). Svaki korisnik knjižnice ima pravo na privatnost, to mu garantiraju međunarodni dokumenti i principi knjižničarskog poslovanja, ali kako kaže Injac (2008), koliko će njegova privatnost uistinu biti zaštićena i poštovana, uvelike ovisi i o profesionalnoj etici knjižničara. Zbog toga je jako važno da su s pravima o zaštiti osobnih podataka upoznati ne samo knjižničari nego i svi korisnici, mediji i ostali tražitelji ili prenositelji informacija (Injac 2008).

Zanimljivo je kako Bowers $(2006,377)$ tumači odnos povjerenja i privatnosti u knjižnici. On kaže da, ako osoba nema osjećaj sigurnosti da će njegovi zapisi u knjižnici biti čuvani u povjerljivosti, to će data collected by the library, there must be a reason why they are requested or for what purposes they will be used (usually data on name and surname, date of birth, occupation, address, telephone number, e-mail, etc.). Data on material borrowing (e.g. on most requested titles) are collected mainly for statistical purposes, in order to plan the acquisition policy. Searches performed by users on computers in libraries also remain recorded and need to be deleted from time to time (Horvat 2002). In addition to user data, the library also stores data on library staff, data on suppliers, donors, etc. (Horvat 2002).

In some countries, the collection of personal data is regulated by legislation concerning libraries, such as in Norway where there is a special public administration body that must give permission to public libraries to collect user data under certain conditions. In the United Kingdom, the Data Protection Act has been in force since 1984, which also applies to libraries, and according to which every head of an institution that collects certain data in machine-readable form is obliged to report that this data is collected. In the United States, there are "regulations on the confidentiality of loan information", and not only that, but even "guarantees the confidentiality of user questions". (Horvat 2002)

From the stated we can conclude that the confidentiality of user data and data on the use of materials and information is important for practical and moral reasons, whereas today, due to easier access to data through the introduction of new information technologies and the existence of various electronic databases, privacy is more compromised than ever before (Gorman 2000, 151). "An individual may therefore rightly fear that unauthorized access to their personal data may prevent them from obtaining a service, privilege, etc. It can also be assumed that the data may not always be accurate or may not be accurately interpreted i.e. they may be interpreted at the expense of the individual" (Horvat 2002). On the other hand, "states are particularly afraid of the possibility that large number of personal data about their citizens may be transferred beyond their borders" (Horvat 2002).

It is clear that without the confidentiality of personal data about an individual, the protection of human privacy is not possible (Injac 2008, 36). Every library user has the right to privacy, which is guaranteed by international documents and principles of library work, but as Injac (2008) says, how much their privacy will truly be protected and respected, depends greatly on the professional ethics of librar- 
ga možda obeshrabriti da istražuje, čita ili traži informacije zbog straha od osude okoline u kojoj živi ili osude društva u cjelini (prema Sutlieff i Chelin 2008, 11). Zato je važno da knjižnice štite privatnost svojih korisnika, podatke o njihovim pretraživanjima, posudbi građe itd. da bi uistinu opravdale svoju ulogu "edukatora privatnosti" (Coombs 2004; Shuler 2004, prema Sutlieff i Chelin 2008, 12) koji bi trebali da u svom poslu potiču i razvijaju svijest korisnika o privatnosti, ističu važnost zaštite osobnih podataka, i ne samo to nego i da dijele s korisnicima informacije o najboljim praksama u području privatnosti i zaštite osobnih podataka i u svakom smislu budu u službi zakona i potreba svojih korisnika.

\section{Pravo na privatnost kao osnovno ljudsko pravo u europskim i međunarodnim dokumentima}

Privatnost je i subjektivno pravo koje pripada svakog građaninu u demokratskoj državi i zajamčeno je međunarodnim dokumentima o ljudskim pravima. Sintagma "pravo na privatnost" je moderno poimanje privatnosti kao pravnog koncepta, a ujedno je i odmak od onoga što je privatnost bila skoro do kraja 19. stoljeća, više filozofski ili moralni koncept. Upravo se ta težnja o pravu na privatnost, kao osobnom pravu svakog pojedinca, ističe već u temeljnom dokumentu o modernom poimanju ljudskih prava Općoj deklaraciji o ljudskim pravima ${ }^{1}$ iz 1948. u članu 12 koji glasi: "Nitko ne smije biti izvrgnut samovoljnom miješanju u njegov privatni život, obitelj, dom ili dopisivanje, niti napadima na njegovu čast i ugled. Svatko ima pravo na zakonsku zaštitu protiv takvog miješanja ili napada."

Polovinom 20. stoljeća, točnije godine 1950., usvojena je i Europska konvencija za zaštitu ljudskih prava $i$ temeljnih sloboda ${ }^{2}$ koja članom 8.1 štiti pravo svakoga pojedinca na poštovanje privatnog $\mathrm{i}$ obiteljskog života, doma i dopisivanja, i u kojoj se naglašava da se javna vlast neće miješati u ostvarivanje tog prava, osim u interesu javne sigurnosti, sprječavanja kaznenih djela i sl.

Međunarodni pakt o građanskim i političkim pravi$m a^{3}$ iz 1966. godine u članu 17 također vrlo slično potvrđuje da "Nitko ne smije biti podvrgnut samovoljnom ili nezakonitom miješanju u njegov privatni život, obitelj ili dopisivanje, niti nezakonitim napadima na njegovu čast ili ugled."

\footnotetext{
Deklaracija usvojena i proglašena na Skupštini UN-a Rezolucijom 217/III.

2 Konvencija potpisana u Rimu, 4. 11. 1950. od strane zemalja članica Vijeća Europe, stupila na snagu 1953.

3 Usvojen Rezolucijom 2200A (XXI) Generalne skupštine 16. 12. 1966., na snagu stupio tek 23. 3. 1976.
}

ians. Therefore, it is very important that the rights to personal data protection are known not only to librarians, but also to all users, media and other seekers or transmitters of information (Injac 2008). It is interesting how Bowers $(2006,377)$ interprets the relationship of trust and privacy in the library. He says that if a person does not have a sense of security that their records in the library will be kept in confidentially, it may discourage them from researching, reading or seeking information for fear of the condemnation of environment in which they live or condemnation of society as a whole (quoted from Sutlieff and Chelin 2008, 11). That is why it is important for libraries to protect the privacy of their users, their search data, material borrowing, etc. in order to truly justify their role as "privacy educators" (Coombs 2004; Shuler 2004; quoted from Sutlieff and Chelin 2008, 12) who should encourage and develop users' awareness of privacy in their work, emphasize the importance of personal data protection, and not only that, but also share with users information on best practices in the field of privacy and personal data protection and in every sense be in the service of the law and the needs of its users.

\section{The right to privacy as a basic human right in Eu- ropean and international documents}

Privacy is also a subjective right that belongs to every citizen in a democratic state and is guaranteed by international human rights documents. The syntagm "right to privacy" is a modern notion of privacy as a legal concept, and at the same time a detachment from what privacy was almost until the end of the $19^{\text {th }}$ century, more a philosophical or moral concept. This aspiration about the right to privacy, as a personal right of every individual, is already emphasized in the basic document on the modern understanding of human rights in the Universal Declaration of Human Rights ${ }^{1}$ from 1948, in Article 12, which reads: "No one shall be subjected to arbitrary interference with his privacy, family, home or correspondence, nor to attacks upon his honour and reputation. Everyone has the right to the protection of the law against such interference or attacks."

In the middle of the $20^{\text {th }}$ century, more precisely in 1950, The European Convention for the Protection of Human Rights and Fundamental Freedoms ${ }^{2}$ was also adopted. The Article 8.1 of this Convention protects the right of every individual on respect for

\footnotetext{
The declaration was adopted and promulgated by the UN Assembly in a Resolution 217/III

2 The Convention, signed in Rome on November 4, 1950 by the member states of the Council of Europe, entered into force in 1953.
} 
Intenzivnija pitanja tajnosti i zaštite osobnih podataka počinju se postavljati od 70-ih godina dvadesetog stoljeća. Posebno je značajna 1974. godina kada je generalni sekretar Ujedinjenih nacija pripremio cjeloviti izvještaj na temu Human rights and scientific and technological development ("Ljudska prava i znanstveno-tehnološki razvoj”). U zaključku ovog izvještaja onim se državama koje nemaju zakonom uređenu zaštitu osobnih podataka preporučuje da to što prije učine. Pri tome procesu UN preporuča i tri načela koja bi članice trebale uvažavati, a to su: načelo određenosti, načelo obavještavanja i načelo pristanka. Načelo određenosti kaže da se mogu sakupljati samo oni osobni podaci koji su nužno potrebni da bi se postigao cilj zbog kojega se sakupljaju. Načelo obavještavanja govori o potrebi da se pojedinca prethodno obavijesti koji se osobni podaci o njemu sakupljaju, a načelo pristanka kaže da se mogu sakupljati samo oni osobni podaci za koje je pojedinac pristao da se sakupljaju.

Poštovanje privatnog i obiteljskog života, doma i komuniciranja ponovno se aktualizira članom 7. u Povelji o temeljnim pravima $E U^{4}$ iz 2000. godine, koja je obuhvatila i čitav niz građanskih, ekonomskih i političkih prava građana EU. U članu 8 potvrđuje se da "svatko ima pravo na zaštitu osobnih podataka (...)" i da se takvi podaci moraju pošteno obrađivati i u određene svrhe, na temelju pristanka osobe na koju se ti isti podaci odnose. Povelja ističe da svatko ima pravo pristupa podacima koji se na njega odnose, kao i pravo na njihovo ispravljanje. Potpisivanjem Ugovora iz Lisabona ${ }^{5} 2009$. postala je pravno obvezujući dokument.

Generalna je skupština UN-a tokom prosinca 2013. usvojila Rezoluciju A/RES/68/167 i revidiranu Rezoluciju u 2014. pod nazivom The right to privacy in the digital age ("Pravo na privatnost $\mathrm{u}$ digitalnom dobu", United Nations 2013) i pozvala sve države da poštuju i štite pravo na privatnost uključujući i ono u digitalnoj komunikaciji, te da poduzimaju mjere za zaustavljanje kršenja tih prava, kao i da usklade vlastita zakonodavstva s tim pravom. Traženo je da se imenuje posebni izvjestitelj, povjerenik UN-a za ljudska prava u području privatnosti. Povjerenik je trebao pripremiti izvještaj o pravu na privatnost $\mathrm{u}$ digitalnom dobu. Ovom Rezolucijom, Generalna skupština prepoznaje globalnu i otvore-

\footnotetext{
Prvi put donesena 7. 12. 2002. Nekoliko puta revidirana. Navedeno prema: Povelja Europske unije o temeljnim pravima 2016/C 202/02 i prema: Priručnik o europskom zakonodavstvu o zaštiti podataka: izdanje iz 2018, 2020.

Ugovor je potpisan 13. prosinca 2007., stupio na snagu 1. prosinca 2009. Vidi više u Sokolska i Pavy 2020
}

private and family life, home and correspondence, and it is emphasized that there shall be no interference by a public authority with the exercise of this right except in the interests of public safety, for the prevention of disorder or crime, etc.

The International Covenant on Civil and Political Right $^{3}$ from 1966 in Article 17 also very similarly confirms that "No one shall be subjected to arbitrary or unlawful interference with his privacy, family, home or correspondence, nor to unlawful attacks on his honour and reputation."

More intense questions of confidentiality and protection of personal data are beginning to be asked in the 1970s. The year 1974 was especially significant when the Secretary-General of the United Nations prepared a comprehensive report on the subject $H u$ man rights and scientific and technological development. In conclusion of this Report, those states that do not have statutory protection of personal data are encouraged to do so as soon as possible. In this process, the UN also recommends three principles that members should respect, and those are: the principle of certainty, the principle of notification and the principle of consent. The principle of certainty states that only those personal data which are needed to achieve the purpose for which they are collected may be collected. The principle of notification speaks of the need to inform the individual in advance what personal data is being collected about them, and the principle of consent states that only those personal data for which the individual has agreed to be collected may be collected.

Respect for private and family life, home and communication is reaffirmed in Article 7 of the $E U$ Charter of Fundamental Rights ${ }^{4}$ from 2000, which included a whole range of civil, economic and political rights of EU citizens. Article 8 confirms that "everyone has the right to the protection of personal data (...)" and that such data must be processed fairly and for certain purposes, with the consent of the person to whom the same data relates. The Charter emphasizes that everyone have the right of access to data relating to them, as well as the right to have it rectified. With the signing of the Lisbon Treaty ${ }^{5}$ in 2009 , it became a legally binding document.

\footnotetext{
Adopted by General Assembly Resolution 2200A (XXI) on 16 December 1966, it entered into force on 23 March 1976.

4 First adopted on December 7, 2002. Revised several times. Quoted according to: Povelja Europske unije o temeljnim pravima 2016/C 202/02 and: Priručnik o europskom zakonodavstvu o zaštiti podataka: izdanje iz 2018, 2020.

5 The treaty was signed on December 13, 2007, and entered into force on December 1, 2009. See more in Sokolska and Pavy 2020.
} 
nu prirodu Interneta i brzinu napretka u informacijskim i komunikacijskim tehnologijama. Također, Rezolucijom se potvrđuje to da ista prava koja ljudi imaju i izvan mreže moraju biti zaštićena i na mreži, uključujući i pravo na privatnost. Vijeće za ljudska prava Rezoluciju RES/28/16 (United Nations $2015)^{6}$ usvaja u travnju 2015. i odlučuje imenovati na tri godine povjerenika za pravo na privatnost. Povjerenik se upućuje na to da podnosi izvještaje o kršenjima prava na privatnost kao i ostale ključne probleme. Države se pozivaju na punu suradnju s povjerenikom. Rezolucije o pravu u digitalnom dobu revidiraju se i donose i 2016. i 2017. godine.

\section{Zaštita osobnih podataka u međunarodnim doku- mentima}

Prve preporuke na području zakonskih legislativa o zaštiti privatnosti i osobnih podataka nastale su 80 ih godina 20. stoljeća u okviru OECD-a (Organisation for Economic, Co-operation and Development - Organizacija za ekonomsku suradnju i razvoj) i Vijeća Europe. OECD je 1980. donio Smjernice o zaštiti privatnosti i međunarodnom prijenosu osobnih podataka (OECD 1980) ${ }^{7}$ (revidirane 2013.), a Vijeće Europe 1981. Konvenciju br. 108 o zaštiti pojedinaca pri automatskoj obradi osobnih podataka. Smjernice OECD-a su istovremeno omogućile i zaštitu privatnosti i prijenos podataka preko granica zemalja članica. Konvencija br. 108 (108 Konvencija o varstvu posameznika glede na avtomatsko obdelavo osebnih podatkov;_v. i Priručniko europskom zakonodavstvu o zaštiti podataka 2020, 26) postala je normom, odnosno "vrijednosnim kriterijumom za informacijske politike zemalja koje su potpisale tu konvenciju" i razvijenim europskim zemljama omogućila poštovanje privatnosti. Konvencija je također definirala neka od temeljnih načela u zaštiti osobnih podataka pojedinaca. Načela se odnose na kvalitetu osobnih podataka, posebne vrste osobnih podataka, osiguranje tih podataka itd. S tim u vezi, osobni podaci koji se obrađuju automatski moraju biti prikupljeni na zakonit način, pohranjeni u određene svrhe, prikladni, primjereni i ne pretjerani s obzirom na svrhe za koje su pohranjeni. Moraju biti točni, pohranjeni u obliku koji dopušta identifikaciju pojedinca na kojega se ti podaci od-

\footnotetext{
Vidi i Priručnik o europskom zakonodavstvu o zaštiti podataka: izdanje iz 2018, 2020.

7 Ovdje ćemo i kratko upozoriti na grešku koja se autorici ovog rada potkrala u netočnom navodu godine OECD Smjernica u prethodnom radu "Pravo na slobodan pristup informacijama u knjižnicama u okvirima međunarodnih dokumenata: između javnosti i privatnosti“", objavljenog u Bosniaca 24 (19), str. 14, gdje umjesto 1981. treba da stoji 1980. godina.
}

In December 2013, the UN General Assembly adopted Resolution A/RES/68/167 and a revised Resolution in 2014 entitled The right to privacy in the digital age (United Nations 2013) and called on all states to respect and protect the right to privacy, including the one in digital communication, and to take measures to stop violations of these rights, and to harmonize their own legislation with this right. It was requested that a special rapporteur, the UN Commissioner for Human Rights in the field of privacy, be appointed. The Commissioner was to prepare a report on the right to privacy in the digital age. With this Resolution, the General Assembly recognizes the global and open nature of the Internet and the speed of progress in information and communication technologies. Also, the Resolution confirms that the same rights that people have offline must be protected online, including the right to privacy. The Human Rights Council adopted Resolution RES/28/16 (United Nations 2015) ${ }^{6}$ in April 2015 and decides to appoint a Commissioner for the Right to Privacy for three years. The Commissioner is instructed to report violations of the right to privacy as well as other key issues. States are called upon to cooperate fully with the Commissioner. Resolutions on the law in the digital age are being revised and passed in 2016 and 2017.

\section{Protection of personal data in international documents}

The first recommendations in the field of legislation on the protection of privacy and personal data were made in the 80 s of the 20 th century within the OECD (Organisation for Economic, Co-operation and Development) and the Council of Europe. In 1980, the OECD adopted the Guidelines on the Protection of Privacy and Transborder Flows of Personal Data ${ }^{7}$ (revised in 2013), and in 1981 the Council of Europe, Treaty No. 108, Convention for the Protection of Individuals with regard to Automatic Processing of Personal Data. The OECD guidelines have at the same time enabled the protection of privacy and the transfer of data across the borders of member countries. Treaty No. 108 (108 Konvencija o varstvu posameznika glede na avtomatsko obdelavo osebnih podatkov; see also Priručnik o europskom

\footnotetext{
See also: Priručnik o europskom zakonodavstvu o zaštiti podataka: izdanje iz 2018, 2020.

7 Here we will briefly point out the mistake that the author of this paper made in the incorrect citation of the year of OECD Guidelines in the previous paper "The right to free access to information in libraries within the framework of international documents: between the public and privacy“, published in Bosniaca 24 (19), p. 14, where instead of 1981, 1980 should be written.
} 
nose i to onoliko dugo koliko je potrebno za svrhe za koje su pohranjeni.

Direktiva 95/46/EZ Europskog parlamenta i Vijeća EU o zaštiti pojedinaca pri obradi osobnih podataka i slobodnom protoku takvih podataka donijeta je 1995. godine. S ovom Direktivom trebali su se uskladiti zakoni pojedinih zemalja članica EU i smatra se najznačajnijim zakonodavnim aktom o zaštiti osobnih podataka u Uniji. Njen je cilj osigurati pravo na zaštitu osobnih podataka i slobodan protok tih podataka među državama članicama. U tom smislu, Direktiva 95/46/EZ zahtijeva od država članica zaštitu temeljnih prava i sloboda fizičkih osoba, a posebno njihovih prava na privatnost pri obradi osobnih podataka, kako bi se osiguralo i slobodno kretanje osobnih podataka u Zajednici.

Dvije godine kasnije donosi se Direktiva 97/66/EZ (Directive 97/66/EC) Europskog parlamenta i Vijeća od 15. prosinca 1997. o obradi osobnih podataka i zaštiti privatnosti u sektoru telekomunikacija. Ovom se direktivom osigurava jednaka razina zaštite temeljnih prava i sloboda, posebno prava na privatnost, s obzirom na obradu osobnih podataka u telekomunikacijskom sektoru, i osigurava se slobodno kretanje takvih podataka u Zajednici. Ova je direktiva prenijela načela navedena u Direktivi 95/46/EZ u pravila za područje telekomunikacija. U Direktivi se naglašava da je potrebno donijeti zakone kojima će se regulirati i prava korisnika i prava onih koji nude određene usluge.

Donošenjem Uredbe (EZ) br. 45/2001 Europskog parlamenta i Vijeća EU o zaštiti pojedinaca u vezi s obradom osobnih podataka u institucijama i tijelima Zajednice i o slobodnom kretanju takvih podataka, štite se ponovno temeljna prava i slobode fizičkih osoba, posebno njihovo pravo na privatnost u vezi s obradom osobnih podataka. Slobodno kretanje osobnih podataka ne smije se ograničiti niti zabraniti, a Uredbom se osniva i Nadzorno neovisno tijelo koje prati primjenu odredbi ove uredbe i uvodi sankcije za prekršitelje odredbi.

Ovdje ćemo spomenuti i dvije direktive posebno aktualne u području elektroničkih komunikacija i javnih komunikacijskih mreža, a to su Direktiva 2002/58/EZ i Direktiva 2006/24/EZ Europskog parlamenta i Vijeća. Direktiva 2002/58/EZ od 12. srpnja 2002. o obradi osobnih podataka i zaštiti privatnosti u području elektroničkih komunikacija (tzv. Direktiva o privatnosti i elektroničkim komunikacijama ili Direktiva o e-privatnosti) "zahtijeva od država članica da osiguraju prava i slobode fizičkih osoba u vezi s obradom osobnih podataka te posebno nji- zakonodavstvu o zaštiti podataka 2020, 26) has become the rule, i.e. "criteria value for the information policies of the signatory countries" and gave an opportunity to developed European countries to respect privacy. The Convention also defined some of the fundamental principles in the protection of personal data of individuals. The principles relate to the quality of personal data, special types of personal data, security of such data, etc. Regarding this, personal data that are automatically processed must be collected lawfully, stored for certain purposes, adequate, appropriate and not excessive in relation to the purposes for which they are stored. They must be accurate, stored in a form that allows the identification of individual to which this data relates and for as long as is necessary for the purposes for which they are stored.

Directive 95/46/EC of the European Parliament and of the Council on the protection of individuals with regard to the processing of personal data and on the free movement of such data was adopted in 1995. This Directive was intended to harmonize the laws of individual EU Member States and is considered to be the most important piece of legislation on the protection of personal data in the Community. Its aim is to ensure the right to the protection of personal data and the free flow of such data between Member States. And in that sense, Directive 95/46/ EC requires Member States to protect the fundamental rights and freedoms of natural persons, and in particular their right to privacy with regard to the processing of personal data, in order to ensure the free movement of personal data within the Community.

Two years later, Directive 97/66/EC of the European Parliament and of the Council of 15 December 1997 concerning the processing of personal data and the protection of privacy in the telecommunications sector was adopted. This Directive ensures an equal level of protection of fundamental rights and freedoms, in particular the right to privacy, with regard to the processing of personal data in the telecommunications sector and ensures the free movement of such data within the Community. This Directive transposed the principles laid out in Directive 95/46/EC into rules in the field of telecommunications. The Directive emphasizes the need to enact laws to regulate both the rights of users and the rights of those offering certain services.

Regulation (EC) No 45/2001 of the European Parliament and of the Council on the protection of individuals with regard to the processing of personal 
hova prava na privatnost, kako bi se osigurao slobodan protok osobnih podataka unutar Zajednice". U ovoj su se direktivi zapravo prevela načela Direktive 95/46/EZ u konkretna pravila za sektor elektroničkih komunikacija. Druga Direktiva 2006/24/EZ od 15. ožujka 2006. o zadržavanju podataka dobivenih ili obrađenih u vezi s pružanjem javno dostupnih elektroničkih komunikacijskih usluga ili javnih komunikacijskih mreža i o izmjeni Direktive 2002/58/EZ, donosi set mjera koje su "zakonodavne mjere kojima bi se osiguralo da se podaci pohranjeni u skladu s ovom Direktivom prosljeđuju nadležnim nacionalnim tijelima samo u skladu s nacionalnim zakonodavstvom i uz puno poštivanje temeljnih prava predmetnih osoba". U tekstu ove Direktive naglašava se da se ona "ne primjenjuje na sadržaj elektroničke komunikacije kao ni na informacije do kojih se dolazi korištenjem elektroničke komunikacijske mreže, ali se osigurava da podaci budu dostupni u svrhu istrage, otkrivanja i progona teških kaznenih djela".

Okvirna odluka Vijeća EU 2008/977 PUP donesena je 27. studenog 2008., a radi se o zaštiti osobnih podataka obrađenih u okviru policijske i pravosudne suradnje u kaznenim stvarima, čija je svrha "osigurati visoku razinu zaštite temeljnih prava i sloboda fizičkih osoba, a osobito njihova prava na privatnost, u pogledu obrade osobnih podataka u okviru policijske i pravosudne suradnje u kaznenim stvarima, uz istodobno jamčenje visoke razine javne sigurnosti".

Dokument novijeg datuma u području zaštite podataka jeste prije svega Uredba (EU) 2016/679 Europskog parlamenta i Vijeća od 27. travnja 2016. o zaštiti pojedinaca u vezi s obradom osobnih podataka i o slobodnom kretanju takvih podataka te o stavljanju izvan snage Direktive 95/46/EZ, poznata još i kao Opća uredba o zaštiti podataka (engl. General Data Protection Regulation - GDPR). Uredba je u primjenu krenula tek 2018., a njome se utvrđuju pravila koja su povezana sa zaštitom pojedinaca $u$ vezi s obradom i kretanjem osobnih podataka, te se štite temeljna prava i slobode pojedinaca (posebno pravo na zaštitu osobnih podataka). Uredba se primjenjuje na osobne podatke koji se automatski obrađuju te na "neautomatiziranu obradu osobnih podataka koji čine dio sustava pohrane ili su namijenjeni biti dio sustava pohrane".

Protokol o izmjeni Konvencije 108 Vijeća Europe za zaštitu osoba glede automatizirane obrade osobnih podataka (ETS br. 108) ${ }^{8}$ dodatni je protokol o

\footnotetext{
Prijedlog Odluke Vijeća o ovlašćivanju država članica da u interesu Europske unije ratificiraju Protokol o izmjeni Konvencije Vijeća Europe za zaštitu osoba glede automatizirane obrade osobnih podataka.
}

data by the Community institutions and bodies and on the free movement of such data, protects fundamental rights and freedoms of natural persons, in particular their right to privacy in connection with processing of personal data. The free movement of personal data may not be restricted or prohibited, and the Regulation also establishes an Independent Supervisory Body that monitors the application of the provisions of this Regulation and introduces sanctions for violators of the provisions.

Here we will mention two directives that are particularly relevant in the field of electronic communications and public communication networks, namely Directive 2002/58/EC and Directive 2006/24/ EC of the European Parliament and of the Council. Directive 2002/58/EC of 12 July 2002 on the concerning the processing of personal data and the protection of privacy in the electronic communications sector (the so-called Directive on privacy and electronic communications or the e-Privacy Directive) "requires Member States to ensure the rights and freedoms of natural persons with regard to the processing of personal data, and in particular their right to privacy, in order to ensure the free flow of personal data in the Community". This directive has in fact translated the principles of Directive 95/46/ EC into specific rules for the electronic communications sector. The Second Directive 2006/24/EC of 15 March 2006 on the retention of data generated or processed in connection with the provision of publicly available electronic communications services or of public communications networks and amending Directive 2002/58/EC lays down a set of measures that are "legislative measures to ensure that data retained under this Directive are provided to the competent national authorities only in accordance with national legislation in full respect of the fundamental rights of the persons concerned". The text of this Directive emphasizes that it "shall not apply to the content of electronic communications, including information consulted using an electronic communications network, but ensures that the data are available for the purpose of the investigation, detection and prosecution of serious criminal offences".

Framework Decision of the EU Council 2008/977/ JHA was adopted on 27 November 2008 and concerns the protection of personal data processed in the framework of police and judicial cooperation in criminal matters, the purpose of which is "to ensure a high level of protection of the fundamental rights and freedoms of natural persons, and in particular their right to privacy, with respect to the processing 
prekograničnom prijenosu podataka u državama koje nisu članice EU i na neki se način ovim protokolom modernizira Konvenciju s početka 80 -ih. Traži se od zemalja članica da u svoja nacionalna zakonodavstva uvrste veću razinu zaštite podataka koja je već osigurana Konvencijom 108, a ovim bi se dodatnim protokolom obuhvatile i sve vrste obrade podataka u okviru nadležnosti stranaka u javnom i privatnom sektoru.

Interesantan je i podatak da je i članom 16. UFEU-a

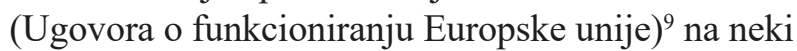
način ozakonjeno pravo na zaštitu osobnih podataka jer se u tom članu navodi da "svatko ima pravo na zaštitu svojih osobnih podataka". S druge strane u članu 15. stav 3. UFEU-a svakoj se fizičkoj ili pravnoj osobi u državama članicama daje pravo na pristup dokumentima institucija, tijela i agencija EU.

Može se reći da je razlog nastanka navedenih dokumenata ustvari bila spoznaja "da masovna obrada osobnih podataka predstavlja objektivnu opasnost za sigurnost informacijske privatnosti pojedinca" i da se države s pravom mogu bojati neovlaštenog pristupa i prijenosa osobnih podataka. S tim u vezi, posebno je opasna velika sposobnost računarskih sustava i tehnologija koji omogućavaju pohranjivanje velikog broja podataka, lak pristup tim podacima te njihovu brzu i jednostavnu reprodukciju. Jasno je da iz toga proizlazi generalni stav o tome koliko je zaštita privatnosti i osobnih podataka važna i potrebna danas, ali i koliko će još više nastaviti biti potrebna i u budućnosti.

\section{Privatnost i osobni podaci u knjižnicama u okviru međunarodnih dokumenata knjižničarskih udruženja}

Knjižnice imaju iznimno značajnu ulogu u promociji i zaštiti privatnosti s obzirom na to da se njihovo djelovanje zasniva na dugoj tradiciji iskustva u radu $\mathrm{s}$ informacijama u svim oblicima i raznim profilima korisnika. "Knjižničari se slažu da je privatnost podataka vitalni dio šire digitalne pismenosti - sposobnost izvlačenja najboljih mogućnosti koje nude digitalne tehnologije i servisi." (prema: IFLA. The right to privacy in the digital age, 3) Knjižnice također promoviraju najbolje prakse u određivanju koji su to korisnički podaci koji se prikupljaju i kakva su ograničenja u tom procesu (v. IFLA. The right to privacy in the digital age, 3 ).

Knjižničarska se struka kao javna služba i ona koja se financira iz javnih sredstava s jedne strane poziva

\footnotetext{
Pročišćene verzije Ugovora o Europskoj uniji i Ugovora o funkcioniranju Europske unije (2016/C 2020/01)
}

of personal data in the framework of police and judicial cooperation in criminal matters, while guaranteeing a high level of public safety".

A more recent document in the field of data protection is primarily Regulation (EU) 2016/679 of the European Parliament and of the Council of 27 April 2016 on the protection of natural persons with regard to the processing of personal data and on the free movement of such data, and repealing Directive 95/46/EC also known as General Data Protection Regulation - GDPR. The Regulation did not enter into force until 2018, and it lays down rules related on the protection of natural persons with regard to the processing of personal data and on the free movement of such data, and protects the fundamental rights and freedoms of natural persons (especially the right to protection of personal data). This Regulation applies to the automated processing of personal data and to the "processing other than by automated means of personal data which form part of a filing system or are intended to form part of a filing system".

Protocol about amending the Council of Europe Convention 108 for the Protection of Individuals with regard to Automatic Processing of Personal Data (ETS No. 108) ${ }^{8}$ is an additional protocol on cross-border data transfer in non-EU countries and in a way this protocol modernizes the Convention from the early 80 's. Member States are required to incorporate into their national legislation a higher level of data protection already provided in Convention 108, and this additional protocol would cover all types of data processing within the competence of the parties in the public and private sectors. Information is also interesting that with Article 16 of TFEU (the Treaty on the Functioning of the European Union) $)^{9}$ in some way legitimized the right to protection of personal data because that article states that "everyone has the right to the protection of personal data concerning them". On the other hand, Article 15 (3) TFEU gives every natural or legal person in the Member States the right to access documents of the EU institutions, bodies and agencies.

It can be said that the reason for the creation of these documents was in fact the realization "that the mass processing of personal data poses an objective threat to the security of information privacy of

\footnotetext{
Proposal for a Council Decision authorising Member States to ratify, in the interest of the European Union, the Protocol amending the Council of Europe Convention for the Protection of Individuals with regard to Automatic Processing of Personal Data.

9 Consolidated versions of the Treaty on European Union and the Treaty on the Functioning of the European Union (2016/C 2020/01).
} 
na slobodan pristup informacijama $\mathrm{u}$ skladu $\mathrm{s}$ načelom javnosti, dok $s$ druge strane $u$ pristupu tim informacijama ipak postoje ograničenja spomenuta već u IFLA-inoj izjavi Knjižnice $i$ intelektualna sloboda ${ }^{10}$ iz 1999, u kojoj se kaže da korisnici knjižnica imaju pravo na privatnost i anonimnost, a knjižničari i ostalo osoblje knjižnica ne smiju otkriti identitet korisnika ili korištene građe trećoj osobi. $\mathrm{U}$ tom smislu, pravo na privatnost u knjižnicama i tajnost osobnih podataka postaju obveze knjižničara u skladu s etikom knjižničarske struke, u skladu sa zakonima, uredbama itd.

"Knjižnice i informacijske službe trebaju poštivati privatnost svojih korisnika te povjerljivost izvora kojima se služe", kratko potvrđuje i IFLA u Manifestu o internetu iz 2002. (IFLA 2002a) iako se dokument u suštini bavio načelima slobode $u$ pristupu informacijama. Ali to nam opet potvrđuje koliko su ova dva segmenta zapravo neodvojivo povezana.

I EBLIDA (European Bureau of Library Information and Documentation Associations) u svojim Preporukama za knjižnično zakonodavstvo i politiku u Europi ${ }^{11}$ iz 2000. jasno ističe da knjižnice trebaju poštovati korisnička prava uključujući i pravo na povjerljivost i privatnost pri korištenju elektroničkih izvora i službi.

Sekcija IFLA-e za slobodan pristup informacijama i slobodu izražavanja objavila je 2002. i zvanični dokument pod nazivom Deklaracija o bibliotekama, informacionim servisima i intelektualnoj slobodi ${ }^{12}$ u kojem kaže da knjižnice i informacijski servisi moraju da garantiraju svakom korisniku tajnost $i$ poštovanje privatnog života, "bilo da se radi o informacijama koje korisnik traži ili dobiva, o dokumentima koje koristi, pozajmljuje, nabavlja ili ih predaje".

Zaštita privatnosti i osobnih podataka kao jedan od najvažnijih knjižničarskih postulata istaknuta je i u IFLA-inom Etičkom kodeksu za knjižničare $i$ druge informacijske djelatnike (IFLA 2012) prema kojem knjižničari treba da poštuju privatnost i zaštitu osobnih podataka, a upravo se odnos knjižnice i korisnika zasniva na povjerljivosti tih podataka. U Kodeksu se navodi i da knjižničari treba da poduzimaju prikladne mjere kako bi osigurali da se

\footnotetext{
${ }^{10}$ Izjavu je odobrio Izvršni odbor IFLA-e 25. ožujka 1999. (IFLA 1999)

11 Tekst Preporuka usvojio je Odbor za kulturu Vijeća Europe u listopadu 1999, a Vijeće za kulturnu suradnju odobrilo ga je u siječnju 2000.

${ }^{12}$ Deklaraciju je odobrio Upravni odbor IFLA-e 27. 3. 2002., na sastanku u Hagu, a usvojena je na drugom sastanku Savjeta IFLAe koji je održan 23. 8. 2002. u Glasgowu. Navedeno prema IFLA $2002 b$.
}

the individual" and that states may rightly fear of unauthorized access and transfer of personal data. With this in regard, the great ability of computer systems and technologies that allow the storage of large amounts of data, easy access to this data, and their quick and easy reproduction is especially dangerous. It is clear that this is a general view of how important and necessary the protection of privacy and personal data is today, but also how much more will continue to be needed in the future.

\section{Privacy and personal data in libraries within the international documents of library associations}

Libraries have an extremely important role in the promotion and protection of privacy, given that their activities are based on a long tradition of experience in working with information in all forms and various user profiles. "Librarians agree that data privacy is a vital part of broader digital literacy the ability to get the best out of the opportunities that digital technologies and services offer" (quoted from IFLA. The right to privacy in the digital age, 3). Libraries also promote best practices in determining what user data is being collected and what the limitations in this process are (see: IFLA. The right to privacy in the digital age, 3).

The library profession as a public service and one financed from public funds on the one hand calls for free access to information in accordance with the principle of publicity, while on the other hand in access to this information there are restrictions mentioned in IFLA's statement Libraries and Intellectual Freedom ${ }^{10}$ from 1999, stating that library users have the right to privacy and anonymity, and that librarians and other library staff must not disclose the identity of users or materials used to third parties. In that sense, the right to privacy in libraries and the confidentiality of personal data become the obligations of librarians in accordance with the ethics of the library profession, in accordance with laws, regulations, etc.

"Libraries and information services should respect the privacy of their users and recognize that the resources they use should remain confidential", briefly confirms IFLA in the Internet Manifesto from 2002 (IFLA 2002a) although the document essentially dealt with the principles of freedom of access to information. But this again confirms to us how inseparably these two segments are actually connected.

\footnotetext{
${ }^{0}$ The statement was approved by the IFLA Executive Board on March 25, 1999 (IFLA 1999).
} 
podaci korisnika koriste isključivo u za to predviđene svrhe, čime se jasno štite korisnički podaci od zlouporaba.

Koliko je privatnost i zaštita osobnih podataka sveprisutna i važna u knjižničarskoj profesiji, govori i činjenica da je IFLA 2015. godine objavila Izjavu o privatnosti u knjižnici ${ }^{13}$ (IFLA Statement on Privacy in the Library Environment, IFLA 2015) $\mathrm{u}$ kojoj vrlo precizno podcrtava da knjižnice i informacijske službe trebaju ne samo poštovati nego i unaprjeđivati privatnost svojih korisnika, da mogu odlučivati koje će osobne podatke o korisnicima prikupljati, na koji će ih način pohranjivati, dijeliti i čuvati i svakako brinuti o sigurnosti tih podataka. Također, Izjavom se knjižnice obvezuju na zagovaranje pitanja vezanih za zaštitu osobne privatnosti i digitalnih prava na svim razinama (međunarodna, državna, lokalna). Knjižnice trebaju odbaciti svako nezakonito praćenje i prikupljanje osobnih podataka kao i podataka o traženim informacijama koje bi ugrozilo privatnost korisnika, te poduzeti mjere za ograničavanje prikupljanja osobnih podataka o korisnicima i uslugama koje korisnici koriste. Knjižničare treba obrazovati uz načela i praksu o zaštiti podataka i privatnosti u umreženom okruženju, a oni trebaju upoznati korisnike s njihovim pravima vezanim za zaštitu privatnosti i osobnih podataka te s posljedicama ugrožavanja te iste privatnosti.

\section{Umjesto zaključka}

Po svemu sudeći, knjižničarska profesija u svom radu neupitno podržava pravo na privatnost kao jedan od vitalnih etičkih segmenata struke, promovirajući najbolje prakse u zaštiti privatnosti i osobnih podataka. Pravo na privatnost i zaštita osobnih podataka zajamčeni su međunarodnim dokumentima i prepoznati kao dio osnovnih ljudskih prava. Međunarodna knjižničarska udruženja također prepoznaju važnost i značaj prava na privatnost i zaštitu osobnih podataka, pa u svojim dokumentima vrlo precizno navode da su to prava koja su knjižničari obvezni da štite u svom radu i koja se u skladu s tajnošću osobnih podataka ne smiju otkrivati trećim osobama, a smije ih se prikupljati samo za određenu svrhu.

Prepoznajući privatnost kao "pravo", odnosno pravni koncept, a ne samo kao "filozofsku", odnosno "moralnu distinkciju", omogućuje se promatranje privatnosti kao nezaobilaznog segmenta u razvoju modernog demokratskog društva i globalne mreže ljudskih prava za svakog građanina.

$\overline{13}$ Dokument je usvojio Glavni odbor IFLA-e 14. 8. 2015.
EBLIDA (European Bureau of Library Information and Documentation Associations) in their Guidelines on Library Legislation and Policy in Europe ${ }^{11}$ from 2000 also clearly states that libraries should respect users' rights, including the right to confidentiality and privacy in the use of electronic resources and services.

The IFLA Section for Free Access to Information and Freedom of Expression also published an official document in 2002 entitled Declaration on Libraries, Information Services and Intellectual Free$d_{o m}{ }^{12}$ which says that libraries and information services must guarantee every user secrecy and respect for privacy, "with respect to information sought or received and resources consulted, borrowed, acquired or transmitted".

The protection of privacy and personal data as one of the most important library postulates is also highlighted in IFLA's Code of Ethics for Librarians and other Information Workers (IFLA 2012) according to which librarians should respect the privacy and protection of personal data, and it is the relationship between the library and the user that is based on the confidentiality of this data. The Code also states that librarians should take appropriate measures to ensure that user data is used exclusively for its intended purpose, clearly protecting user data from misuse.

How ubiquitous and important is privacy and personal data protection in the library profession, tells also the fact that IFLA published in 2015 Statement on Privacy in the Library Environment ${ }^{13}$ (IFLA 2015) which emphasizes very precisely that libraries and information services should not only respect but also improve the privacy of their users, that they can decide what personal information about users should be collected, how to store it, share and keep it and also take care of the security of this data. Also, with the Statement libraries commit to advocate the issues related to the protection of personal privacy and digital rights at all levels (international, national, local). Libraries should reject any illegal monitoring and collection of personal data as well as data on requested information that would endanger the privacy of users, and take measures to restrict the

\footnotetext{
11 Text of Guidlines was adopted by Committee for Culture at the Council of Europe in October 1999, and Council for Cultural Co-operation approved it in January 2000.

${ }^{12}$ Declaration was approved by the Governing Board of IFLA on 27 March 2002 at the meeting in Hague, but was proclaimed by on the second meeting of Council of IFLA which was held on 19 August 2002 in Glasgow. Quoted from IFLA 2002b.

13 The document was adopted by the IFLA Main Board on August 14, 2015.
} 
S obzirom na sve veće prisustvo modernih tehnologija i interneta u svakodnevnom životu, privatnost i osobne podatke postaje sve teže zaštititi. Osobni se podaci štite zakonima o zaštiti osobnih podataka, što potkrjepljujemo pregledom međunarodnih dokumenata o zaštiti osobnih podataka i u ovom radu.

Možemo reći da je pravo na privatnost i zaštitu osobnih podataka u knjižnicama ustvari moguće promatrati negdje na razmeđu međusobnog odnosa u trijadi privatnost - osobni podaci - knjižnica. collection of personal data about users and services used by users. Librarians should be educated in accordance with the principles and practices of data protection and privacy in a networked environment, and they should inform users about their rights related to the protection of privacy and personal data and the consequences of compromising the same privacy.

\section{Instead of a conclusion}

By all accounts, the library profession unquestionably supports the right to privacy in its work as one of the vital ethical segments of the profession, promoting best practices in the protection of privacy and personal data. The right to privacy and the protection of personal data are guaranteed by international documents and recognized as part of basic human rights. International librarians' associations also recognize the importance and significance of the right to privacy and protection of personal data, and in their documents state very precisely that these are rights that librarians are obliged to protect in their work, and which must not be disclosed to third parties and may only be collected for a specific purpose.

Recognizing privacy as a "right" or legal concept, and not just as a "philosophical" or "moral distinction", allows us to view privacy as an indispensable segment in the development of a modern democratic society and a global network of human rights for every citizen.

With the growing presence of modern technologies and the Internet in everyday life, privacy and personal data are becoming increasingly difficult to protect. Personal data is protected by personal data protection laws, which we support by reviewing international documents on personal data protection in this paper as well.

We can say that the right to privacy and protection of personal data in libraries can actually be observed somewhere at the crossroads of the relationship in the triad privacy - personal data - library. 


\section{Literatura i izvori / Bibliography and sources}

- 108 Konvencija o varstvu posameznika glede na avtomatsko obdelavo osebnih podatkov. http://www.svetevrope.si/sl/dokumenti_in publikacije/konvencije/108/. Datum pristupa: 25. 10. 2020.

- Bowers, Stacey L. 2006. "Privacy and library records" Journal of Academic Librarianship 32 (4): 377-383.

- Brezak, Milan. 1997. Ozbiljenje ustavnog prava na osobnost pravnom zaštitom podataka: usporedno pravi $i$ informacijski pristup. Doktorska disertacija, Sveučilište u Zagrebu.

- Clarke, Robert. 2006. "Introduction to Dataveillance and Information Privacy, and Definition of Terms" http://www.rogerclarke.com/DV/Intro. html. Datum pristupa: 15. 10. 2020.

- Cohen, Julie E. 2013. "What privacy is for?" Harvard Law Review 126 (7). https:// harvardlawreview.org/2013/05/what-privacy-isfor/. Datum pristupa: 20. 10. 2020.

- Coombs, Karen A. 2004. "Walking a tightrope: academic libraries and privacy" The Journal of Academic Librarianship 30 (6): 493-498.

- Directive 97/66/EC of the European Parliament and of the Council of 15 December 1997 concerning the processing of personal data and the protection of privacy in the telecommunications sector. https://eur-lex.europa.eu/legal-content/ EN/TXT/?uri=CELEX\%3A31997L0066. Datum pristupa: 18. 10. 2020.

- Direktiva95/46/EZEuropskog parlamentaiVijeća od 24. listopada 1995. o zaštiti pojedinaca u vezi s obradom osobnih podataka i o slobodnom protoku takvih podataka. https://eur-lex.europa.eu/legalcontent/HR/TXT/?uri=celex\%3A31995L0046. Datum pristupa: 15. 10. 2020.

- Direktiva 2002/58/EZ Europskog parlamenta i Vijeća od 12. srpnja 2002. o obradi osobnih podataka i zaštiti privatnosti u području elektroničkih komunikacija (Direktiva o privatnosti i elektroničkim komunikacijama). https://eur-lex.europa.eu/legal-content/HR/ TXT/?uri=CELEX\%3A32002L0058. Datum pristupa: 18. 10. 2020.

- Direktiva 2006/24/EZ Europskog parlamenta i Vijeća od 15. ožujka 2006. o zadržavanju podataka dobivenih ili obrađenih u vezi s pružanjem javno dostupnih elektroničkih komunikacijskih usluga ili javnih komunikacijskih mreža i o izmjeni Direktive 2002/58/EZ. https:/eur-lex. europa.eu/legal-content/HR/TXT/?uri=celex\%3A32006L0024. Datum pristupa: 15. 10. 2020.
- Europska konvencija za zaštitu ljudskih prava i temeljnih sloboda. https://www.zakon.hr/z/364/ (Europska)-Konvencija-za-za\%C5\%A1 tituljudskih-prava-i-temeljnih-sloboda. Datum pristupa: 18. 10. 2020.

- Glancy, J. Dorothy. 1979. "The invention of the right to privacy" Arizona Law Review 21 (1): 1-39.

- Gorman, Michael. 2000. Our enduring values: librarianship in the 21st century. Chicago, London: ALA.

- Horvat, Aleksandra. 2002. "Javno i tajno u knjižničarskoj struci” U 5. seminar Arhivi, knjižnice, muzeji: mogućnosti suradnje u okruženju globalne informacijske infrastrukture: zbornik radova, uredile Mirna Willer i Tinka Katić, 8-15. Zagreb: Hrvatsko knjižničarsko društvo. http://dzs.ffzg.unizg.hr/text/jit_u_\%20 knjiz.pdf. Datum pristupa: 8. 10. 2020.

- Horvat, Aleksandra, i Daniela Živković. 2012. Između javnosti i privatnosti: knjižnice u vremenu e-knjige. Zagreb: Hrvatska sveučilišna naklada.

- IFLA. The right to privacy in the digital age. https://www.ifla.org/files/assets/faife/ochr privacy_ifla.pdf. Datum pristupa: 23. 10. 2020.

- IFLA. 2012. Etički kodeks za knjižničare $i$ druge informacijske djelatnike. Priredili Loida Garcia-Febo, Anne Hustad, Hermann Rösch, Paul Sturges i Amelie Vallotton. https:// www.ifla.org/files/assets/faife/codesofethics/ croatiancodeofethicsfull.pdf. Datum pristupa: 20 . 9. 2020.

- IFLA. 1999. Knjižnice i intelektualna sloboda. Hrvatsko knjižničarsko društvo. http://dzs.ffzg. unizg.hr/text/kiis.htm. Datum pristupa: 8. 10. 2020.

- IFLA. 2002a. Manifest o internetu. https://www. ifla.org/files/assets/faife/publications/policydocuments/internet-manifesto-hr.pdf. Datum pristupa: 23. 10. 2020.

- IFLA. 2002b. The Glasgow Declaration on Libraries, Information Services and Intellectual Freedom. S engleskog prevela Vesna Injac. https:// www.ifla.org/publications/the-glasgow-declaration-on-libraries-information-services-and-intellectual-freedom. Datum pristupa: 20. 10. 2020.

- IFLA. 2015. Izjava o privatnosti u knjižnici. Prevela Aleksandra Horvat. https://www. hkdrustvo.hr/clanovi/alib/datoteke/file/IFLAina\%20Izjava\%20o\%20privatnosti.pdf. Datum pristupa: 20. 10. 2020. 
- Injac, Vesna. 2008. "Privatnost u virtuelnom okruženju" Glasnik Narodne biblioteke Srbije 1: 35-50. https://www.nb.rs/view_file.php?file $\mathrm{id}=2589$. Datum pristupa: 28. 8. 2020.

- Law, Jonathan. 2015. Oxford Dictionary of Law. Oxford: Oxford University Press.

- Michael, James. 1994. Privacy and human rights. Paris: UNESCO; Aldershot: Dartmouth Publishing.

- Međunarodni pakt o građanskimi političkim pravima. http://wp.ffzg.unizg.hr/hre-edc/files/2015/02/Zbirka-me $\%$ C4\%91 unarodnih-i-doma\%C4\%87ih-dokumenata.pdf. Datum pristupa: 18. 9. 2020.

- McMenemy, David. 2016. "Rights to privacy and freedom of expression in public libraries: squaring the circle". https://pureportal.strath.ac.uk/files-asset/54531639/McMenemy_IFLA_2016_rights to_privacy_and_freedom_of_expression_in_public_libraries.pdf. Datum pristupa: 25.9.2020.

- Okvirna odluka Vijeća 2008/977/PUP od 27. studenoga 2008. o zaštiti osobnih podataka obrađenih u okviru policijske i pravosudne suradnje u kaznenim stvarima. https://eur-lex. europa.eu/legal-content/HR/TXT/?uri=CELEX:32008F0977. Datum pristupa: 12. 10. 2020.

- Opća deklaracija o ljudskim pravima. http://www. mvep.hr/custompages/static/hrv/files/081210 deklaracija_ljudska_prava.pdf. Datum pristupa: 20. 10. 2020.

- Pavuna, Andro. 2019. “Transformacija pojma prava na privatnost kao posljedica razvoja tehnologije i novih sigurnosnih izazova" Doktorski rad, Sveučilište u Zagrebu.

- Platon. 2009. Država. Zagreb: Naklada Jurčić.

- Povelja Europske unije o temeljnim pravima 2016/C 202/02. https://eur-lex.europa.eu/legalcontent/HR/TXT/PDF/?uri=CELEX:12016P/ TXT\& from=RO. Datum pristupa: 20. 10. 2020.

- Preporuke za knjižnično zakonodavstvo i politiku $u$ Europi. 2000. Preveo s engleskog Krešimir Pintarić. Vjesnik bibliotekara Hrvatske 43 (3): 161-162. http://dzs.ffzg.unizg.hr/text/preporuke. pdf. Datum pristupa: 1. 9. 2020.

- Priručnik o europskom zakonodavstvu o zaštiti podataka: izdanje iz 2018. 2020. Luksemburg: Ured za publikacije Europske unije. https:// www.echr.coe.int/Documents/Handbook_data protection_HRV.pdf. Datum pristupa: 20.9.2020.

- Pročišćene verzije Ugovora o Europskoj uniji i Ugovora o funkcioniranju Europske unije (2016/C 2020/01). https://eur-lex.europa.eu/legal-content/ $\mathrm{HR} / \mathrm{TXT} /$ ?uri=CELEX\%3A12016ME\%2FTXT. Datum pristupa: 24. 10. 2020.
- Prijedlog Odluke Vijeća o ovlašćivanju država članica da u interesu Europske unije ratificiraju Protokol o izmjeni Konvencije Vijeća Europe za zaštitu osoba glede automatizirane obrade osobnih podataka (ETS br. 108). https:// eur-lex.europa.eu/legal-content/HR/TXT/ $\mathrm{PDF} /$ ?uri=CELEX:52018PC0451\& from $=\mathrm{EN}$. Datum pristupa: 3. 10. 2020.

- Sutlieff, Lisa, i Jackie Chelin. 2008. “'An absolute prerequisite': The importance of user privacy and trust in maintaining academic freedom at the library" From a dissertation submitted November, 2007 (Fieldwork completed June August, 2007). file://C:/Users/User/Downloads/ JOLISarticle6_final_rev\%20(2).pdf. Datum pristupa: $23.10 .20 \overline{20}$.

- Schneier, Bruce. 2015. Data and Goliath. New York; London: W. W. Norton Company.

- Shuler, John. 2004. "Privacy and academic libraries: widening the frame of discussion" The Journal of Academic Librarianship 30 (2): 157159.

- Sokolska, Ina, i Eeva Pavy. 2020. "Ugovor iz Lisabona" Europski parlament, 2. 2020. https:// www.europarl.europa.eu/factsheets/hr/sheet/5/ the-treaty-of-lisbon.

- United Nations. 1974. Human rights and scientific and technological development. https:// digitallibrary.un.org/record/1629645? ln=en. Datum pristupa: 20. 10. 2020.

- United Nations. 2013. A/RES/68/167. The right to privacy in the digital age. http://undocs.org/A/ RES/68/167 Datum pristupa: 24. 10. 2020.

- United Nations. 2015. A/HRC/RES/28/16. The right to privacy in the digital age. https://undocs. org/en/A/HRC/RES/28/16. Datum pristupa: 20. 10. 2020.

- Uredba (EZ) br. 45/2001 Europskog parlamenta i Vijeća od 18. prosinca 2000. o zaštiti pojedinaca u vezi s obradom osobnih podataka u institucijama i tijelima Zajednice i o slobodnom kretanju takvih podataka. https://eur-lex.europa.eu/legalcontent/HR/TXT/?uri=celex\%3A32001R0045. Datum pristupa: 24. 10. 2020.

- Uredba (EU) 2016/679 Europskog parlamenta i Vijeća od 27. travnja 2016. o zaštiti pojedinaca u vezi s obradom osobnih podataka i o slobodnom kretanju takvih podataka te o stavljanju izvan snage Direktive 95/46/EZ (Opća uredba o zaštiti podataka). https://eur-lex.europa.eu/legalcontent/HR/TXT/?uri=celex\%3A32016R0679. Datum pristupa: 24. 10. 2020. 
- Warren, Samuel D., i Louis D. Brandeis. 1890. "The right to privacy" Harvard Law Review 4 (5): 193-220. http://law.scu.edu/wp-content/uploads/ Privacy.pdf. Datum pristupa: 1. 10. 2020.
- Westin, Alan F. 1967. Privacy and Freedom. New York: Atheneum. 